
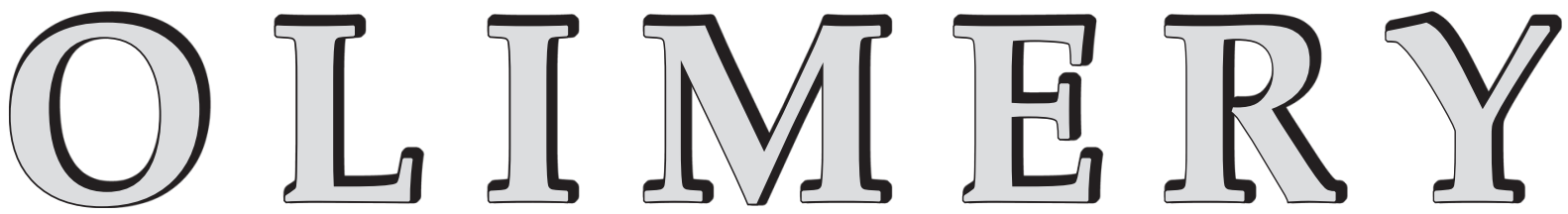

\title{
Zwiększanie skali procesu jednoślimakowego wytłaczania tworzyw polimerowych
}

\author{
Andrzej Nastaj') ${ }^{\text {*) }}$ (ORCID ID: 0000-0002-5040-6733) \\ DOI: dx.doi.org/10.14314/polimery.2021.6.1
}

\begin{abstract}
Streszczenie: Na podstawie badań symulacyjnych opracowano metodę zwiększania skali procesu jednoślimakowego wytłaczania tworzyw polimerowych, z zastosowaniem technik ewolucyjnych (algorytmów genetycznych). Do symulacji procesu wytłaczania stosowano program GSEM (Global Screw Extrusion Model), a do zwiększenia skali specjalnie w tym celu opracowany program GASES (Genetic Algorithms Screw Extrusion Scaling). Jako kryteria stosowano jednostkowe zużycie energii, szybkość uplastyczniania i szybkość wzrostu temperatury tworzywa. Uzyskano znaczący wzrost wydajności procesu wytłaczania.
\end{abstract}

Słowa kluczowe: wytłaczanie jednoślimakowe, skalowanie, modelowanie numeryczne.

\section{Scale-up for single screw extrusion of polymeric materials}

\begin{abstract}
A method of scaling-up the single screw extrusion of polymeric materials has been developed based on the process simulation studies using the evolutionary techniques (genetic algorithms). The simulation tests were carried out using the GSEM extrusion simulation program, while the scaling-up was carried out on the basis of the GASES evolutionary scaling-up program specially developed for this purpose. Scaling-up has been performed according to the criteria of unit energy consumption, polymer melting rate and polymer temperature, obtaining a significant increase in extrusion throughput.
\end{abstract}

Keywords: single screw extrusion, scaling-up, computer modeling.

Komputerowe modelowanie jest efektywnym narzędziem do projektowania procesów przetwórstwa tworzyw polimerowych. Systemy CAD/CAE, jakkolwiek użyteczne przy projektowaniu procesów przetwórczych, nie umożliwiają ich optymalizacji wg określonych kryteriów. Optymalizacja procesu wytłaczania jest zagadnieniem złożonym ze względu na często ze sobą sprzeczne kryteria oraz bardzo dużą liczbę danych procesowych (materiałowych, geometrycznych i technologicznych). Polega na tworzeniu wielowymiarowej przestrzeni parametrów wyjściowych procesu (przestrzeni odpowiedzi)

\footnotetext{
1) Politechnika Warszawska, Instytut Technik Wytwarzania, ul. Narbutta 85, 02-524 Warszawa.

*) Autor do korespondencji: andrzej.nastaj@pw.edu.pl
}

na podstawie parametrów wejściowych i poszukiwaniu w tej przestrzeni wartości ekstremalnych. Dane do optymalizacji mogą być pozyskiwane na podstawie badań doświadczalnych lub symulacyjnych, przy czym bardziej efektywna jest optymalizacja na podstawie danych symulacyjnych.

Istnieje wiele różnych metod optymalizacji, np. statystyczne. Istotną wadą tych metod jest konieczność prowadzenia badań $\mathrm{w}$ przestrzeni odpowiedzi o bardzo dużej gęstości danych oraz niebezpieczeństwo uzyskiwania rozwiązań lokalnych, a nie globalnych.

Znane są metody modelowania i optymalizacji procesów fizycznych przy zastosowaniu sztucznej inteligencji (sieci neuronowych, algorytmów genetycznych, systemów rozmytych), które dostarczają rozwiązań ciągłych 
lub dyskretnych, przy uwzględnieniu procesu uczenia na podstawie dostępnych danych. Szczególne znaczenie w przypadku wytłaczania mają metody optymalizacji na podstawie algorytmów genetycznych. Znalazły one zastosowanie do optymalizacji procesu wytłaczania jednoślimakowego bez dozowania [1-6], wytłaczania dwuślimakowego współbieżnego [7-9] i ostatnio wytłaczania jednoślimakowego z dozowaniem [10-12]. Brakuje natomiast doniesień dotyczących optymalizacji procesu wytłaczania dwuślimakowego przeciwbieżnego, pomimo że zostały opracowane odpowiednie modele matematyczne tego procesu [13-16].

Algorytmy genetyczne charakteryzują się następującymi cechami:

- parametry zadania są przetwarzane w postaci zakodowanej,

- poszukiwanie rozwiązania jest prowadzone z określonej populacji punktów, co minimalizuje prawdopodobieństwo wyznaczenia ekstremum lokalnego,

- stosowane są probabilistyczne reguły wyboru,

- korzysta się tylko z funkcji celu, a nie z jej pochodnych.

Ważną metodą projektowania procesów fizycznych jest zwiększanie ich skali wg określonych kryteriów poprzez przenoszenie wyników badań z urządzenia np. laboratoryjnego do przemysłowego. Początkowo, zwiększanie skali procesu wytłaczania było realizowane na podstawie jednoparametrowych kryteriów, które charakteryzowały jedynie wybrane cechy procesu. Zastosowanie modelu komputerowego umożliwia zwiększenie skali na podstawie charakterystyki całego procesu wytłaczania. Zastosowanie znajdują tutaj techniki optymalizacji prowadzące do minimalizacji rozbieżności między parametrami procesów skalowanych. Tak więc, rozwiązania modelowe i optymalizacyjne stanowią podstawę do zwiększania skali procesów przetwórczych.

\section{ZWIĘKSZANIE SKALI}

Zwiększanie skali procesu przetwórstwa polega np. na zwiększeniu jego wydajności tak, aby różnice między parametrami charakteryzującymi proces odniesienia i proces wynikowy (skalowany) była minimalne.
W zależności od potrzeb wskazuje się określone kryteria zwiększania skali (parametry charakteryzujące proces) oraz ich wagi (znaczenie). Podstawą koncepcji jest teoria podobieństwa, która określa zależności pomiędzy parametrami fizycznymi mającymi wpływ na badane zjawisko (np. przepływ tworzywa w układzie uplastyczniającym wytłaczarki). Spełnienie tych zależności zapewnia zachowanie podobieństwa pomiędzy dwoma układami o różnej wielkości. Schemat ideowy zwiększania skali przedstawiono na rys.1.

Zwiększanie skali procesu przetwórstwa polega na definiowaniu parametrów geometrycznych i technologicznych procesu w taki sposób, aby ten proces był realizowany tak jak proces odniesienia.

Zwiększanie skali procesu wytłaczania było omawiane w wielu monografiach, np. Rauwendaala [17], Hensena i innych [18], McKelvey'a [19], Stevensa i Covasa [20], Campbella i Spaldinga [21], Chunga [22], Chena i innych. [23]. Przedstawione koncepcje polegały na definiowaniu podstawowych zmiennych (średnica ślimaka, długość ślimaka, głębokość kanału ślimaka, prędkość obrotowa ślimaka) na podstawie zależności

$$
\frac{X_{2}}{X_{1}}=\left(\frac{D_{2}}{D_{1}}\right)^{x}
$$

gdzie: $X_{1}$ i $X_{2}$ - zmienne zwiększenia skali, $D_{1}$ i $D_{2}-$ średnica ślimaka, $x$ - współczynnik zwiększenia skali; 1 - skala mniejsza, 2 - skala większa

Pierwszą koncepcję zwiększenia skali przedstawili Carley i Mc Kelvey [24], którzy analizowali przepływ tworzywa w strefie dozowania układu uplastyczniającego wytłaczarki i zaproponowali podobieństwo geometryczne ślimaków (głębokość i szerokość kanału) proporcjonalnie do stosunku średnicy tych ślimaków, przy stałej prędkości obrotowej. W rezultacie uzyskali

$$
\frac{G_{2}}{G_{1}}=\left(\frac{D_{2}}{D_{1}}\right)^{3}
$$

\section{WYTŁACZARKA ODNIESIENIA $D_{1}$}

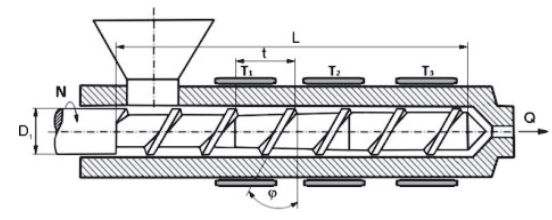

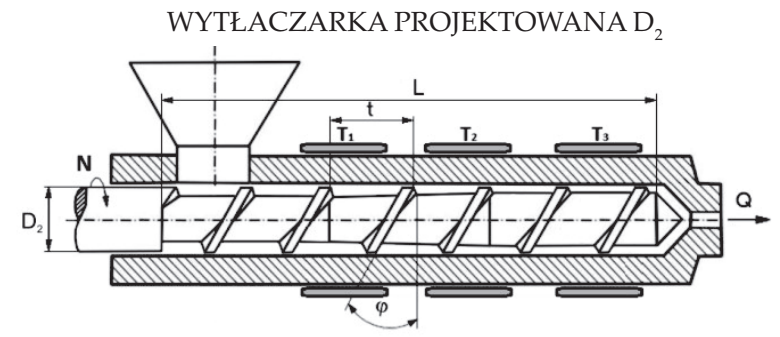

Rys. 1. Koncepcja zwiększania skali procesu wytłaczania: $D_{1}$ - średnica ślimaka wytłaczarki odniesienia, $D_{2}-$ średnica ślimaka wytłaczarki projektowanej

Fig. 1. The concept of scaling-up the extrusion process: $D_{1}$ - the reference extruder screw diameter, $D_{2}-$ the target extruder screw diameter 


$$
\frac{P_{2}}{P_{1}}=\left(\frac{D_{2}}{D_{1}}\right)^{3}
$$

gdzie: $G$ - natężenie przepływu tworzywa, $D$ - średnica ślimaka, $P-$ moc.

Przedstawiano również inne metody zwiększania skali, wśród których można wyróżnić koncepcje Maddocka [25,26], Fennera i innych [27,28], Pearsona [29], Potente i Fischera [30], Schenkela [31], Chunga [32], Rauwendaala [33] i Potente [34].

Pearson [29], jako pierwszy, przedstawił koncepcje odnoszącą się do całego procesu wytłaczania, uwzględniającą transport tworzywa w stanie stałym, uplastycznianie tworzywa oraz przepływ w strefie dozowania. $\mathrm{Wg}$ tej koncepcji, przy zachowaniu jednakowego kąta linii śrubowej ślimaka i jednakowej temperatury cylindra, uzyskuje się podobieństwo procesu przy zachowaniu równości liczb Graetza, Brinkmana i Nahme w poszczególnych strefach układu uplastyczniającego wytłaczarki.

Covas i Cunha [35] stwierdzili m.in., że dotychczasowe koncepcje zwiększania skali procesu wytłaczania funkcjonują tylko w odniesieniu do pojedynczych parametrów, np. szybkości ścinania czy szybkości uplastyczniania i w odniesieniu do pojedynczej strefy układu uplastyczniającego, np. dozowania czy zasilania, a ich podstawę stanowią uproszczone modele zjawisk fizycznych zachodzących $\mathrm{w}$ procesie przetwórstwa.

Autorzy [35] uznali, że potrzebne są metody oparte na dokładnym modelu matematycznym procesu, umożliwiające równoczesne rozpatrywanie różnych kryteriów. Stwierdzili również, że wymagania te mogą być spełnione przy takim zdefiniowaniu parametrów geometrycznych i technologicznych, aby wartości kryteriów procesu odniesienia i zwiększania skali były jak najbardziej zbliżone do siebie. Celem zwiększania skali jest więc minimalizacja różnic między wartościami wybranych parametrów odpowiedzi obu procesów.
Tak ujęta koncepcja zwiększania skali (rys. 2) wymaga następujących działań:

- symulacji procesu w celu uzyskania powierzchni odpowiedzi wytłaczarki odniesienia przy zadanych parametrach geometrycznych i technologicznych procesu,

- zdefiniowania kryteriów zwiększania skali,

- ustalenia parametrów stałych wytłaczarki projektowanej (większa skala), np. średnicy ślimaka czy stosunku długości ślimaka do średnicy,

- realizacji procedury zwiększania skali przez minimalizację różnic między wartościami wybranych parametrów obu procesów.

Podstawowe znaczenie przy zwiększaniu skali ma wybór kryteriów. Zwykle uwzględnia się szybkość ścinania, natężenie przepływu tworzywa, czas przebywania tworzywa w układzie uplastyczniającym wytłaczarki, jednostkowe zużycie energii, tak jak proponują Rauwendaal [33] i Potente [34]. Covas i Cunha [35] dodają stosunek wydajności procesu wytłaczania do natężenia przepływu wleczonego tworzywa, szybkość uplastyczniania, definiowaną przez długość układu uplastyczniającego (ślimaka) konieczną do uplastycznienia tworzywa, rozpraszanie energii aproksymowane przez temperaturę tworzywa oraz stopień wymieszania tworzywa.

Kryteria zwiększania skali można rozważać jako funkcje celu F, które trzeba zminimalizować

$$
F_{i}=\frac{\left|C_{i}-C_{i}^{r}\right|}{C_{i}^{r}}
$$

gdzie: $F_{i}$ - funkcja celu $i$-tego kryterium, $C_{i}$ i $C_{i}^{r}$ - wartości $i$-tego kryterium odpowiednio dla wytłaczarki projektowanej (większa skala) i wytłaczarki odniesienia (referencyjnej).

Covas i Cunha [36-38] oraz Berzin i inni [39] przedstawili także koncepcje zwiększania skali procesu wytłaczania dwuślimakowego współbieżnego. Zagadnienia te zostały ostatnio podsumowane w pracy przeglądowej [40].

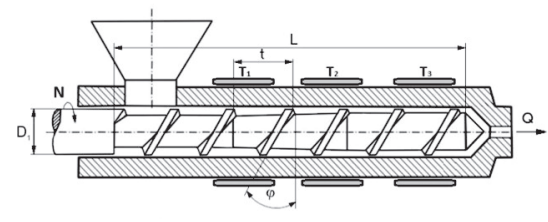

Parametry wejściowe

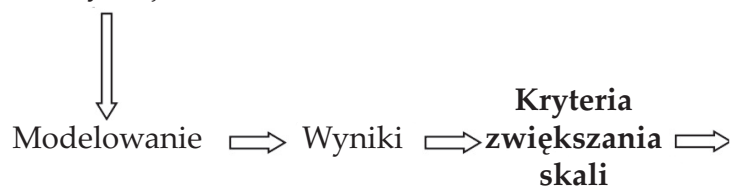

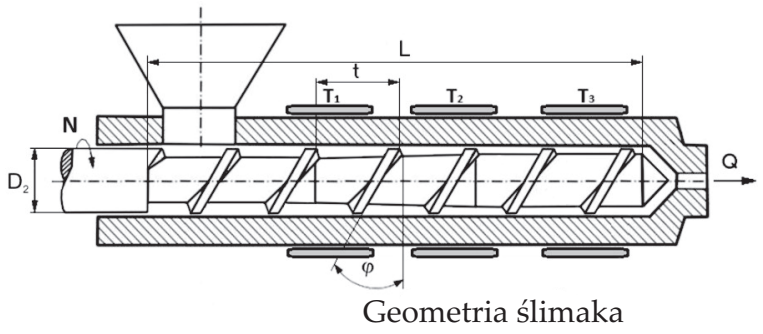

Warunki technologiczne

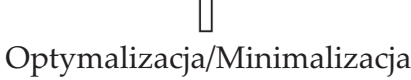

Rys. 2. Koncepcja optymalizacji projektowanego procesu wytłaczania: $D_{1}-$ średnica ślimaka wytłaczarki odniesienia, $D_{2}-$ średnica ślimaka wytłaczarki projektowanej

Fig. 2. The concept of optimization of extrusion process: $D_{1}$ - the reference extruder screw diameter, $D_{2}-$ the target extruder screw diameter 


\section{PROGRAM DO ZWIĘKSZANIA SKALI}

Proponowane zwiększenie skali procesu wytłaczania na podstawie technik ewolucyjnych polega na pozyskiwaniu danych na podstawie badań symulacyjnych procesu i następnie zastosowaniu odpowiedniej procedury ewolucyjnej (algorytmów genetycznych). Wymaga to współdziałania dwóch narzędzi, pozyskiwania danych i obróbki tych danych.

Podstawę badań symulacyjnych stanowi program GSEM (ang. Global Screw Extrusion Model) [41], który jest rozwinięciem znanego programu symulacji konwencjonalnego procesu wytłaczania jednoślimakowego bez dozowania SSEM (ang. Single Screw Extrusion Model) [42]. Program GSEM umożliwia symulację procesu wytłaczania jednoślimakowego z dozowaniem na podstawie rozwiązań przedstawionych w pracach [43-45]. Dalsze badania procesu wytłaczania $\mathrm{z}$ zastosowaniem ślimaków o specjalnej konstrukcji $[46,47]$ oraz wytłaczania mieszanin polimerowych $[48,49]$ i wytłaczania kompozytów drzewnych $[50,51]$ doprowadziły do opracowania wielozadaniowego systemu modelowania przepływu tworzyw polimerowych w wytłaczarkach jednoślimakowych bez dozowania i z dozowaniem tworzywa, ze ślimakami konwencjonalnymi i o specjalnej konstrukcji, przy zastosowaniu głowic o różnej geometrii. Podstawy modelowania procesu wytłaczania przedstawiono ostatnio w pracy przeglądowej [52].

Do zwiększania skali procesu wytłaczania zastosowano specjalnie opracowany program GASES (Genetic Algorithms Screw Extrusion Scaling) wykorzystujący algorytmy genetyczne, który współpracuje z programem symulacji GSEM (Global Screw Extrusion Model) stanowiącym źródło danych.

Zwiększanie skali na podstawie algorytmów genetycznych obejmuje następujące etapy:

1. Zdefiniowanie globalnej funkcji celu (kryterium zwiększenia skali)

W tej pracy globalną funkcję celu zdefiniowano $\mathrm{w}$ postaci

$$
F_{i s}=\left|1-\frac{f_{i(1) A}}{f_{i(1) B}}\right|+\left|1-\frac{f_{i(2) A}}{f_{i(2) B}}\right|+\ldots+\left|1-\frac{f_{i(k) A}}{f_{i(k) B}}\right|
$$

gdzie: $F_{i s}$ - globalna funkcja celu dla zwiększenia skali i-tego zestawu danych, $k$ - liczba kryteriów zwiększenia skali (wielkości wyjściowych procesu), $f_{i(k) A}$ - wartość wielkości wyjściowej dla wytłaczarki odniesienia, $f_{i(k) B}$ - wartość wielkości wyjściowej dla wytłaczarki projektowanej (większa skala)

2. Określenie zakresu zwiększanych wielkości.

3. Zdefiniowanie wielkości wyjściowych procesu odniesienia.

4. Zdefiniowanie algorytmu genetycznego: a. określenie sposobu kodowania wielkości wejściowych,

b. określenie długości ciągu znaków kodujących poszczególne parametry wejściowe procesu, która wyznacza dokładność poszukiwań $\mathrm{w}$ przestrzeni decyzyjnej,

c. określenie wielkości „populacji” wejściowej,

d. przyjęcie sposobu selekcji chromosomów,

e. ustalenie prawdopodobieństwa wystąpienia operatorów krzyżowania i mutacji,

f. ustalenie kryterium zatrzymania ewolucji.

5. Realizacja procedury ewolucyjnej (algorytmów genetycznych):

a. losowy wybór populacji początkowej, czyli inicjacja procedury,

b. ocena jakości chromosomów w populacji na podstawie wartości funkcji celu,

c. ocena warunku zatrzymania ewolucji,

d. wybór (selekcja) chromosomów do następnej populacji,

e. wykonanie operacji genetycznych krzyżowania i mutacji,

f. generacja nowej populacji,

g. wybór rozwiązania o najmniejszej wartości funkcji celu.

Program GASES umożliwia zwiększenie skali procesu wytłaczania $z$ dowolnie określoną liczbą zmiennych, przy różnych kryteriach, np. jednostkowego zużycia energii czy szybkości uplastyczniania. Dokładność badania powierzchni odpowiedzi jest określona przez liczbę przedziałów zakresu danych, która wynika z długości zapisu tych liczb $\mathrm{w}$ postaci binarnej. $\mathrm{W}$ programie GASES długość ciągu binarnego jest regulowana, przy maksymalnej długości 255 znaków. Umożliwia to podział zakresu zmiennych na $2^{255}$ wartości. Przy selekcji zastosowano metodę „koła ruletki”, której implementacja komputerowa jest względnie prosta. Warunkiem zatrzymania procedury zwiększenia skali jest 100-krotne wystąpienie najlepszego zestawu danych.

Program GASES umożliwia swobodny dobór parametrów ewolucji:

- długości chromosomów (ciągów znaków kodujących),

- wielkości populacji początkowej,

- prawdopodobieństwa wystąpienia krzyżowania i mutacji oraz liczby punktów krzyżowania.

Schemat blokowy algorytmu programu zwiększenia skali GASES (we współpracy z programem GSEM) przedstawiono na rys. 3 .

\section{CZĘŚĆ DOŚWIADCZALNA}

Program badań obejmował zwiększenie skali procesu wytłaczania z poziomu wytłaczarki odniesienia o średnicy ślimaka $\mathrm{D}=45 \mathrm{~mm}$ do poziomu wytłaczarki projektowanej o średnicy ślimaka $\mathrm{D}=60 \mathrm{~mm}$ przy zachowaniu stosunku długości ślimaka do średnicy L/D (rys.4). 


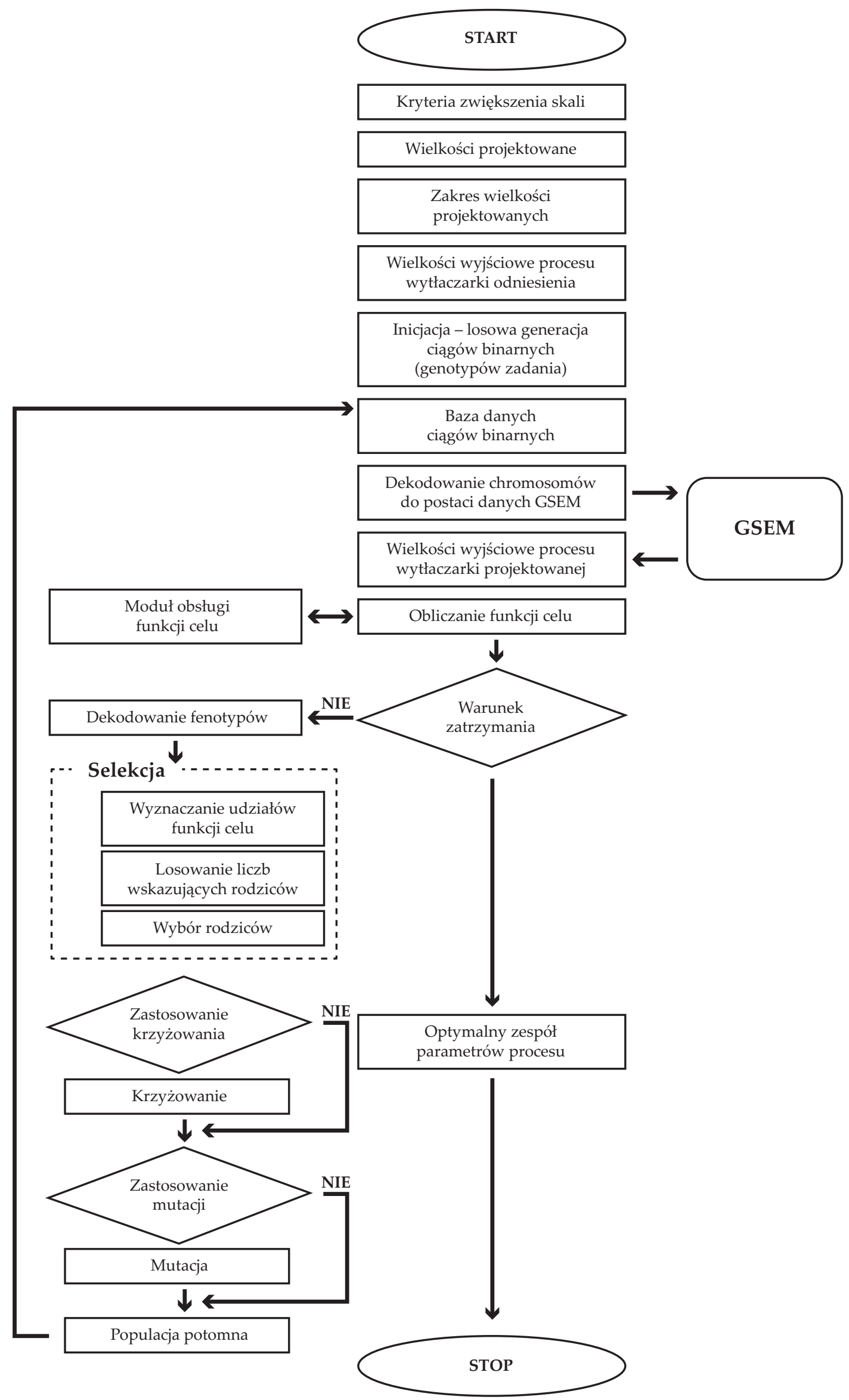

Rys. 3. Schemat blokowy algorytmu programu GASES (we współpracy z programem GSEM)

Fig. 3. The block diagram of the GASES program algorithm (in co-operation with GSEM). 

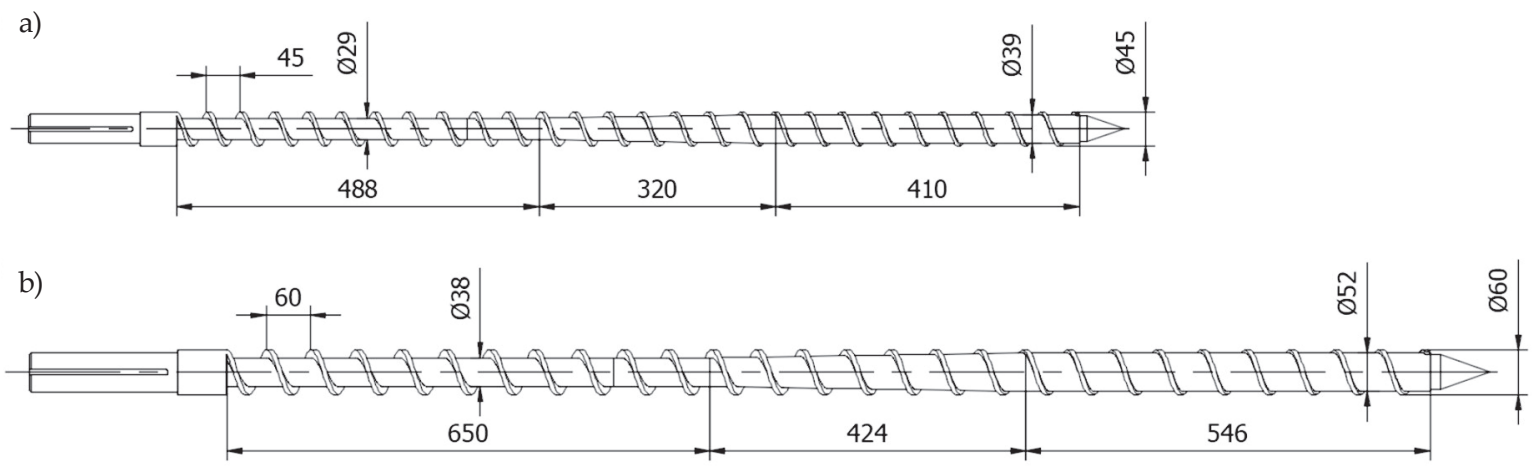

Rys.4. Geometria ślimaka: a) wytłaczarka odniesienia, b) wytłaczarka projektowana

Fig.4. Extruder screw geometry: a) reference extruder, b) target extruder

Badania wykonano w odniesieniu do polietylenu dużej gęstości (PE-HD)-Rigidex 6070EA (firmy BP Chemicals) o gęstości $0,952 \mathrm{~g} / \mathrm{cm}^{3}$, wskaźniku szybkości płynięcia $\operatorname{MFR}=7,6 \mathrm{~g} / 10 \mathrm{~min}\left(190^{\circ} \mathrm{C}, 2,16 \mathrm{~kg}\right)$ i temperaturze topnienia $135^{\circ} \mathrm{C}$.

Właściwości reologiczne tworzywa opisano na podstawie równania Kleina

$$
\ln \eta=A_{0}+A_{1} \ln \dot{\gamma}+A_{11} \ln ^{2} \dot{\gamma}+A_{12} T \ln ^{2} \dot{\gamma}+A_{2} T+A_{22} T
$$

gdzie: $\eta$ - lepkość, $\dot{\gamma}$ - szybkość ścinania, $T$ - temperatura; $A_{0}, A_{1}, A_{11}, A_{12}, A_{2}$ i $A_{22}$ - parametry równania Kleina $\left(A_{0}=1,092 \cdot 10^{1}, A_{1}=-2,184 \cdot 10^{-1}, A_{11}=-3,687 \cdot 10^{-2}\right.$, $\left.A_{12}=1,026 \cdot 10^{-3}, A_{2}=-2,268 \cdot 10^{-2}, A_{22}=2,115 \cdot 10^{-5}\right)$.

Zwiększenie skali przeprowadzono w odniesieniu do procesu wytłaczania, którego parametry technologiczne ustalono w wyniku optymalizacji. Optymalizacja procesu odniesienia została przeprowadzona wg kryterium maksymalnej wydajności $Q_{\max }$ minimalnego jednostkowego zużycia energii $E_{j \min }$ i minimalnej temperatury tworzywa na wyjściu z głowicy $T_{\text {tw min }}$.

Globalną funkcję celu zdefiniowano w postaci

$$
F_{i o}=\sqrt[3]{Q_{i_{-} \text {znorm }} \cdot E_{j i_{-} \text {znorm }} \cdot T_{\text {twi_znorm }}}
$$

gdzie poszczególne dane ze zbioru wielkości wyjściowych znormalizowano w postaci

$$
\begin{gathered}
Q_{i_{-} \text {znorm }}=\frac{Q_{i}-Q_{\text {min }}}{Q_{\text {max }}-Q_{\text {min }}} \\
E_{j i_{-} \text {znorm }}=\frac{E_{j i}-E_{j \min }}{E_{j \max }-E_{j \min }} \\
T_{t w i_{-} \text {znorm }}=\frac{T_{t w i}-E_{t w \text { min }}}{E_{t w \max }-E_{t w \min }}
\end{gathered}
$$

gdzie: $F_{i o}$ - globalna funkcja celu procedury optymalizacji, $Q_{i \text { znorm }}$ - znormalizowana wartość masowego natężenie przepływu tworzywa, $E_{j i \_n o r m}-$ znormalizowana wartość jednostkowego zużycia energii, $T_{\text {tw iznorm }}-$ znormalizowana wartość temperatury tworzywa na wyjściu z głowicy, $i$ - numer kolejnej wartości ze zbioru danych.

Optymalizacja procesu odniesienia została wykonana w zakresie prędkości obrotowej ślimaka $\mathrm{N}=20-80 \mathrm{obr} . / \mathrm{min}$ oraz temperatury cylindra w kolejnych strefach układu uplastyczniającego wytłaczarki: $T_{\mathrm{I}}=150^{\circ} \mathrm{C}, T_{\mathrm{II}}=150-$ $240^{\circ} \mathrm{C}, \mathrm{T}_{\mathrm{III}}=150-240^{\circ} \mathrm{C}, \mathrm{T}_{\mathrm{IV}}=150-240^{\circ} \mathrm{C}$.

Najwyższą wartość funkcji celu uzyskano przy prędkości obrotowej ślimaka $N=80$ obr./min i temperaturze cylindra: $\mathrm{T}_{\mathrm{I}}=150^{\circ} \mathrm{C}, \mathrm{T}_{\mathrm{II}}=193^{\circ} \mathrm{C}, \mathrm{T}_{\mathrm{III}}=180^{\circ} \mathrm{C}, \mathrm{T}_{\mathrm{IV}}=180^{\circ} \mathrm{C}$. Tym optymalnym parametrom, wg przyjętych kryteriów optymalizacji maksymalnej wydajności, minimalnego jednostkowego zużycia energii i minimalnej temperatury tworzywa na wyjściu z głowicy, odpowiadają określone wartości wielkości wyjściowych procesu tj. masowe natężenie przepływu $Q=27 \mathrm{~kg} / \mathrm{h}$, jednostkowe zużycie energii $E_{j}=489 \mathrm{~kJ} / \mathrm{kg}$ i temperatura tworzywa na wyjściu z głowicy: $T_{t w}=255^{\circ} \mathrm{C}$.

W odniesieniu do tak zoptymalizowanego procesu odniesienia zwiększono skalę procesu wytłaczania, w analogicznym zakresie danych wejściowych prędkości obrotowej ślimaka $N=20 \div 80 \mathrm{obr}$./min i temperatury cylindra $T_{\mathrm{I}}=150^{\circ} \mathrm{C}, T_{\mathrm{II}}=150-240^{\circ} \mathrm{C}, T_{\mathrm{III}}=150-240^{\circ} \mathrm{C}$, $T_{\text {IV }}=150-240^{\circ} \mathrm{C}$.

Zwiększenie skali przeprowadzono wg kryterium jednostkowego zużycia energii $E_{j}$, temperatury tworzywa na wyjściu z głowicy $T_{\text {tw }}$ i względnej „długości uplastyczniania" $L_{\text {uplast }}$ wyrażonej stosunkiem długości ślimaka niezbędnej do uplastycznienia tworzywa do całkowitej długości ślimaka.

Globalna funkcja celu została zdefiniowana jako

$$
F_{i s}=\left|1-\frac{E_{j_{A}}}{E_{j_{B} i}}\right|+\left|1-\frac{T_{t w_{A}}}{T_{t w_{B} i}}\right|+\left|1-\frac{L_{\text {uplast }_{A}}}{E_{\text {uplast }_{B} i}}\right|
$$

gdzie: $F_{i s}$ - globalna funkcja celu zwiększania skali procesu, $E_{i A}$ - jednostkowe zużycie energii wytłaczarki odniesienia, $E_{j B i}$ - jednostkowe zużycie energii wytłaczarki projektowanej, $T_{t w A}$-temperatura tworzywa na 
wyjściu z głowicy wytłaczarki odniesienia, $T_{t w B}$-temperatura tworzywa na wyjściu z głowicy wytłaczarki projektowanej, $L_{\text {uplast } A}$ - względna "długość uplastyczniania” wytłaczarki odniesienia, $L_{\text {uplast B } i}$ - względna "długość uplastyczniania" wytłaczarki projektowanej, $i$ - numer kolejnej wartości ze zbioru danych.

\section{WYNIKI BADAŃ I ICH OMÓWIENIE}

Przykładowe wyniki badań symulacji procesu wytłaczania przedstawiono na rys. 5. Pokazano ogólną charakterystykę procesu, która obejmuje podstawowe parametry, rozkład ciśnienia i temperatury tworzywa, pobór mocy, przebieg uplastyczniania tworzywa oraz stopień wypełnienia ślimaka. Przebieg uplastyczniania tworzywa jest określany przez profil uplastyczniania SBP (ang. Solid Bed Profile), który jest wyznaczany przez stosunek objętości tworzywa w stanie stałym (ang. solid) do całkowitej objętości tworzywa w danym obszarze ślimaka. W przypadku klasycznego wytłaczania bez dozowania jest to stosunek szerokości warstwy stałej tworzywa $X$ (ang. solid bed) do szerokości kanału ślimaka $W$, czyli $S B P=X / W$. W początkowej części ślimaka, gdy kanał jest całkowicie wypełniony tworzywem nieuplastycznio-

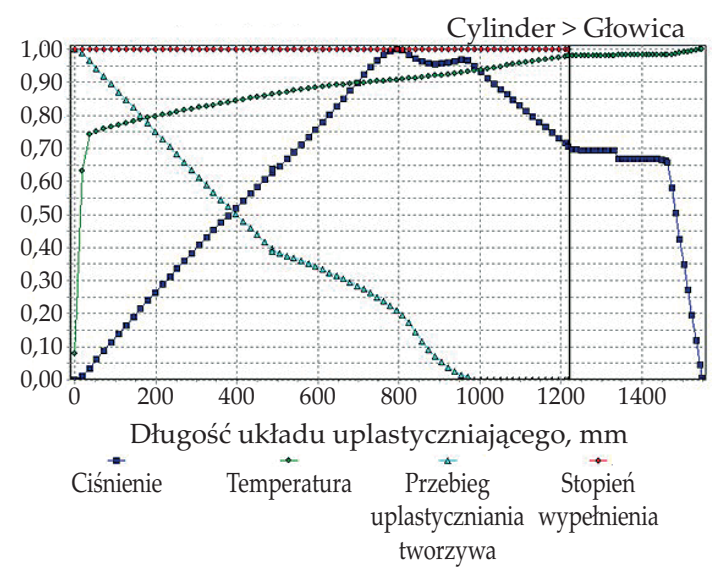

Rys.5. Ogólna charakterystyka procesu wytłaczania (wytłaczarka podstawowa), prędkość obrotowa ślimaka $\mathrm{N}=60 \mathrm{obr} . / \mathrm{min}$ Fig. 5. General characteristics of the extrusion process (basic extruder), screw speed $\mathrm{N}=60 \mathrm{rpm}$

a)

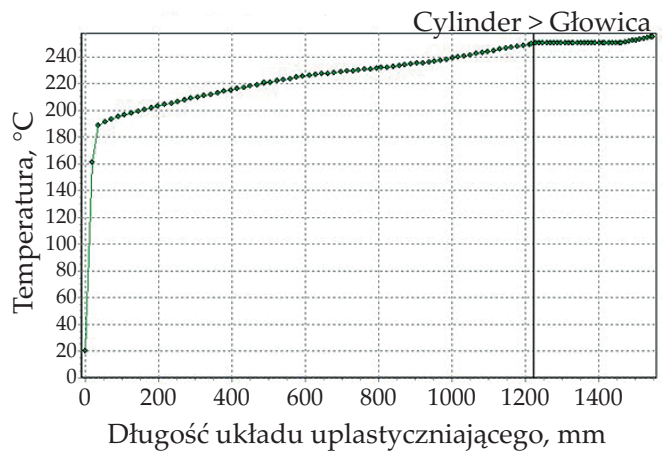

T a b e l a 1. Wyniki badań dotyczące zwiększania skali procesu wytłaczania

$\mathrm{T}$ a b l e 1. Results of scaling-up the extrusion process

\begin{tabular}{l|c|c|c}
\hline \multicolumn{1}{c|}{ Parametr } & $\begin{array}{c}\text { Wytłaczarka } \\
\text { odniesienia } \\
\text { D45 }\end{array}$ & $\begin{array}{c}\text { Wytłaczarka } \\
\text { projektowana } \\
\text { D60 }\end{array}$ & $\begin{array}{c}\text { Różnica } \\
\%\end{array}$ \\
\hline $\begin{array}{l}\text { Jednostkowe } \\
\text { zużycie energii, } \\
\text { kJ/kg }\end{array}$ & 489,36 & 470,64 & 3,83 \\
$\begin{array}{l}\text { Temperatura } \\
\text { tworzywa na } \\
\text { wyjściu z głowicy, } \\
{ }^{\circ} \text { C }\end{array}$ & 254,88 & 254,95 & 0,03 \\
$\begin{array}{l}\text { Względna ,długość } \\
\text { uplastyczniania" }\end{array}$ & 0,796 & 0,823 & 3,49 \\
$\begin{array}{l}\text { Wydajność } \\
\text { wytłaczania, kg/h }\end{array}$ & 27,10 & 49,61 & 83,06 \\
\hline
\end{tabular}

nym, $S B P=1$, natomiast w części końcowej, gdy tworzywo jest uplastycznione, $S B P=0$. Na podstawie profilu $S B P$ można ocenić, czy tworzywo uplastyczni się w wytłaczarce. Długość układu uplastyczniającego, w którym zachodzi uplastycznianie jest ważnym parametrem projektowania procesu wytłaczania i stanowi podstawowe kryterium zwiększania skali procesu [35].

Stopień wypełnienia ślimaka FF (ang. fill factor) jest wyznaczany przez stosunek objętości tworzywa w danej objętości kanału ślimaka do objętości kanału. Kanał jest całkowicie wypełniony tworzywem, gdy stopień wypełnienia $F F=1$, natomiast jest pusty, gdy stopień wypełnienia $F F=0$. Kanał ślimaka jest częściowo wypełniony, gdy stopień wypełnienia mieści się $\mathrm{w}$ zakresie $0<F F<1$. W przypadku wytłaczania bez dozowania stopień wypełnienia jest zwykle, chociaż nie zawsze, równy jedności na całej długości układu uplastyczniającego wytłaczarki. Warto przy tym zwrócić uwagę, że ciśnienie jest generowane jedynie w obszarze całkowitego wypełnienia ślimaka, czyli gdy $F F=1$. Gdy ślimak nie jest całkowicie wypełniony, czyli gdy $0<F F<1$, ciśnienie nie jest generowane.

Pozostałe dwa parametry procesu tj. pobór mocy i temperatura tworzywa stanowią podstawę do obliczenia jednostkowego zużycia energii i rozpraszania energii [35].

Uzyskane wyniki przedstawiono w tab. 1 oraz na rys. 6 i 7 .

b)

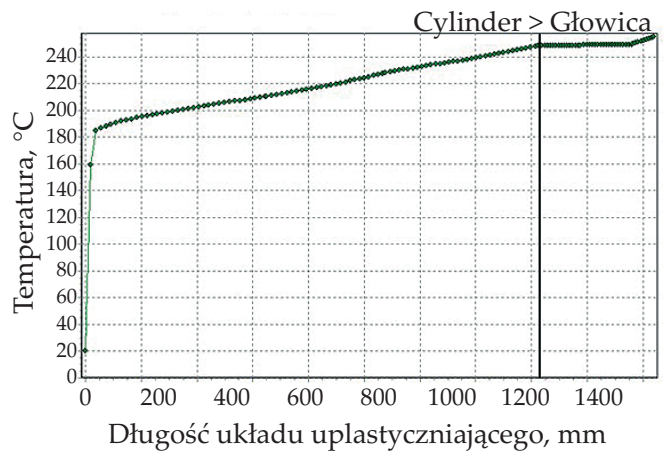

Rys. 6. Rozkład temperatury tworzywa: a) wytłaczarka odniesienia D45, b) wytłaczarka projektowana D60

Fig. 6. Temperature profile: a) reference extruder, b) target extruder 
a)

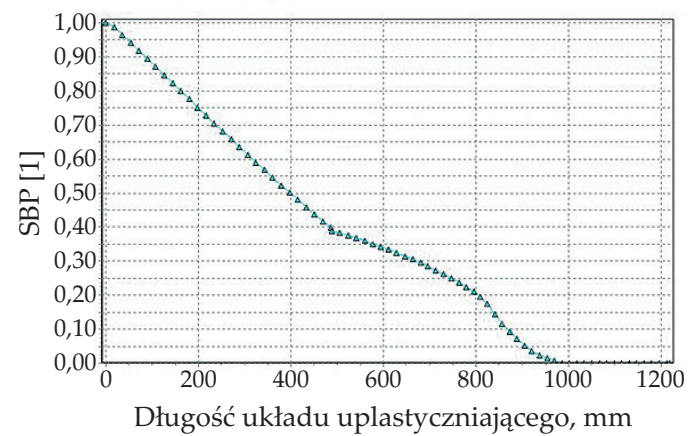

b)

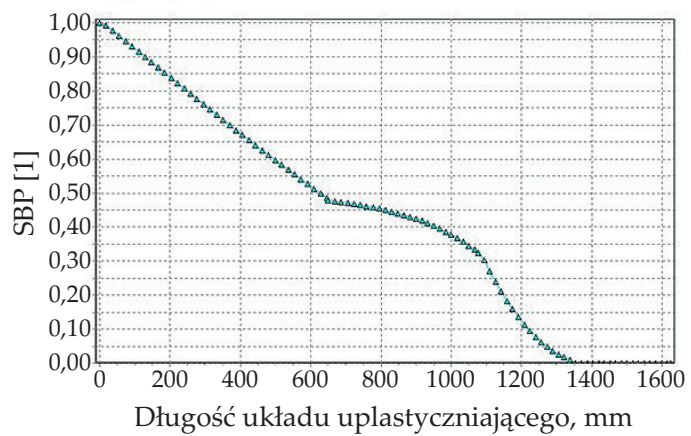

Rys. 7. Przebieg procesu uplastyczniania tworzywa (SBP): a) wytłaczarka odniesienia D45, b) wytłaczarka projektowana D60 Fig. 7. Polymer melting course (SBP): a) reference extruder, b) target extruder

Najmniejszą wartość funkcji celu (11), czyli minimum rozbieżności między parametrami procesu odniesienia i procesu projektowanego uzyskano przy prędkości obrotowej ślimaka $\mathrm{N}=60 \mathrm{obr}$./min i temperaturze cylindra $\mathrm{T}_{\mathrm{I}}=150^{\circ} \mathrm{C}, \mathrm{T}_{\mathrm{II}}=180^{\circ} \mathrm{C}, \mathrm{T}_{\mathrm{III}}=223^{\circ} \mathrm{C}, \mathrm{T}_{\mathrm{IV}}=206^{\circ} \mathrm{C}$. Tym parametrom odpowiadają następujące wartości wielkości wyjściowych procesu projektowanego tj. jednostkowe zużycie energii Ej=471 kJ/kg, temperatura tworzywa na wyjściu z głowicy $\mathrm{T}_{\mathrm{tw}}=255^{\circ} \mathrm{C}$ i względna „długość uplastyczniania" $\mathrm{L}_{\text {uplast }}=0,823$. Różnice wartości pomiędzy parametrami procesu odniesienia i procesu projektowanego są niewielkie (tabl.1). Tak więc, można stwierdzić, że ze względu na wybrane kryteria oba procesy są podobne. Wskazują na to także wyniki symulacji rozkładu temperatury i przebiegu uplastyczniania tworzywa w wytłaczarce odniesienia i wytłaczarce projektowanej (rys.6 i 7). Przez zwiększenie skali procesu uzyskano znaczący wzrost wydajności procesu wytłaczania (tabl.1).

Proces wytłaczania jest definiowany przez kilkadziesiąt parametrów materiałowych, technologicznych i geometrycznych, a potencjalnych kryteriów może być nawet kilkanaście.

Przedstawiona metoda zwiększania skali wskazuje na przewagę badań symulacyjnych nad doświadczalnymi. Wiadomo, że liczba prób eksperymentalnych $i_{\text {exp }}$ jest definiowana potęgową zależnością liczby zwiększanych wartości parametrów $n$ i liczby poziomów wartości tych parametrów $k \mathrm{w}$ postaci $i_{\text {exp }}=k^{n}$. Tak więc, przykładowo, zwiększenie wartości tylko czterech parametrów technologicznych procesu wytłaczania, np. prędkości obrotowej ślimaka i temperatury w 3 strefach cylindra, przy wykonaniu badań na 4 poziomach wartości tych parametrów, wymagałaby wykonania $i_{\text {exp }}=4^{4}=256$ prób doświadczalnych. Dodanie tylko dwóch parametrów geometrycznych, np. długości strefy zasilania i strefy dozowania układu uplastyczniającego, a więc zwiększenie liczby optymalizowanych parametrów do sześciu, spowodowałoby konieczność wykonania $i_{\text {exp }}=4^{6}=4096$ prób doświadczalnych.

Zakres badań przeprowadzonych w pracy nie byłby praktycznie do osiągnięcia w warunkach doświadczalnych. Do kodowania parametrów zastosowano ciąg binarny o długości 7 znaków, co oznacza $2^{7}=128$ poziomów wartości. Tak więc, zwiększanie skali dla czterech parametrów technologicznych procesu wytłaczania tj. prędkości obrotowej ślimaka i temperatury w 3 strefach cylindra, przy wykonaniu badań na 128 poziomach wartości tych parametrów, wymagałoby wykonania $i_{\text {exp }}=128^{4}=268435456\left(2,68 \cdot 10^{8}\right)$ prób doświadczalnych . Zmiana prędkości obrotowej przy tym ciągu binarnym wynosi 0,5 obr./min, natomiast zmiana temperatury $0,7^{\circ} \mathrm{C}$.

\section{PODSUMOWANIE}

Opracowano metodę zwiększania skali procesu wytłaczania jednoślimakowego tworzyw na podstawie badań symulacyjnych z wykorzystaniem technik ewolucyjnych. Do badań zastosowano specjalnie opracowany program GASES. Pod uwagę wzięto kryteria, takie jak: jednostkowe zużycie energii, szybkość uplastyczniania tworzywa i temperatura tworzywa. Uzyskano znaczący wzrost wydajności procesu wytłaczania. Wykazano, że zwiększanie skali na podstawie badań doświadczalnych jest bardziej czasochłonne i kosztowne oraz trudniejsze do wykonania.

Opracowana metoda ma charakter uniwersalny i może być zastosowana do innych procesów, np. wytłaczania dwuślimakowego. Numeryczna implementacja metody wymaga jednak każdorazowo dostosowania do określonego procesu przetwórczego. Warunkiem stosowania tej metody jest również dostęp do kodu źródłowego odpowiedniego modelu komputerowego badanego procesu, co wymaga opracowania własnego modelu. Prace w tym zakresie są prowadzone w niewielu ośrodkach badawczych na świecie posiadających doświadczenie w modelowaniu procesów przetwórczych, jak i zagadnieniach optymalizacji i zwiększania skali.

\section{LITERATURA}

[1] Covas J.A., Gaspar-Cunha A., Oliveira P.: International Journal of Forming Processes 1998, 1, 323. 
[2] Covas J.A., Gaspar-Cunha A., Oliveira P.: Polymer Engineering and Science 1999, 39 (3), 443. https://doi.org/10.1002/pen.11434

[3] Covas J.A., Gaspar-Cunha A.: „The Use of an Optimisation Approach to the Design of Extrusion Screw", Materiały konferencyjne The Polymer Processing Society Sixteenth Annual Meeting (PPS-16), Szanghaj, Chiny, 2000.

[4] Gaspar-Cunha A., Covas J.A.: International Polymer Processing 2001, 16 (3), 229. https://doi.org/10.3139/217.1652

[5] Nastaj A., Wilczyński K.: Polimery 2018, 63 (1), 38. https://doi.org/10.14314/polimery.2018.1.6

[6] Nastaj A., Wilczyński K.: Polimery 2018, 63 (4), 297. https://doi.org/10.14314/polimery.2018.4.7

[7] Gaspar-Cunha A., Covas J.A., Vergnes B.: "An Optimisation Methodology for Setting the Operating Conditions in Twin-Screw Extrusion", Materiały konferencyjne The Polymer Processing Society Eighteenth Annual Meeting (PPS-18), Guimaraes, Portugalia, 2002.

[8] Gaspar-Cunha A., Poulesquen A., Vergnes B., Covas J.A.: International Polymer Processing 2002, 17 (3), 201. https://doi.org/10.3139/217.1701

[9] Gaspar-Cunha A., Covas J.A., Vergnes B.: Polymer Engineering and Science 2005, 45 (8), 1159. https://doi.org/10.1002/pen.20391

[10] Nastaj A.: Polimery 2020, 65 (5), 380. https://doi.org/10.14314/polimery.2020.5.6

[11] Nastaj A.: Polimery 2020, 65 (6), 468. https://doi.org/10.14314/polimery.2020.6.6

[12] Nastaj A., Wilczyński K.: Polymers 2020, 12 (1), 149. https://doi.org/10.3390/polym12010149

[13] Wilczyński K., White J.L.: Polimery 2008, 53 (10), 754. https://doi.org/10.14314/polimery.2008.754

[14] Wilczyński K., Nastaj A., Lewandowski A., Wilczyński K.J.: Polimery 2011, 56 (1), 45

https://doi.org/ 10.14314/polimery.2011.045

[15] Wilczyński K., Lewandowski A., Wilczyński K.J.: Polymer Engineering and Science 2012, 52 (6), 1258. https://doi.org/10.1002/pen.23076

[16]Lewandowski A., Wilczyński K.J., Nastaj A., Wilczyński K.: Polymer Engineering and Science 2015, 55 (12), 2838. https://doi.org/10.1002/pen.24175

[17] Rauwendaal C.: "Polymer Extrusion", Carl Hanser Verlag, Munich 2014.

[18] Hensen F., Knappe W., Potente H.: „Handbuch der Kunststoff-Extrusiontechnik. Grundlagen”, Carl Hanser Verlag, Munich 1989.

[19] McKelvey J.M.: "Polymer Processing", John Wiley \& Sons Inc., New York 1962.

[20] Stevens M.J., Covas J.A.: „Extruder Principles and Operation", Springer Berlin Heidelberg 1995.

[21] Campbell G.A., Spalding M.A.: "Analyzing and Troubleshooting Single-Screw Extruders", Carl Hanser Verlag, Munich 2013.
[22] Chung C.I: "Extrusion of Polymers -- Theory and Practice", Carl Hanser Verlag, Munich 2019.

[23] Chen B., Zhu L., Zhang F. et al.: "Process Development and Scale-Up. In Developing Solid Oral Dosage Forms", Elsevier, Amsterdam 2017, str. 821.

[24] Carley J.F., McKelvey J.M.: Industrial and Engineering Chemistry 1953, 45 (5), 989.

https://doi.org/10.1021/ie50521a036

[25] Maddock B.H.: SPE Journal 1959, 15, 383.

[26] Maddock B.H.: Polymer Engineering and Science 1974, 14 (12), 853. https://doi.org/10.1002/pen.760141208

[27] Fenner R.T., Williams J.G.: Polymer Engineering and Science 1971, 11 (6), 474. https://doi.org/10.1002/pen.760110606

[28] Yi B., Fenner R.T.: Plastics and Rubber Processing and Applications 1976, 1, 119.

[29] Pearson J.R.A.: Plastics and Rubber Processing and Applications 1976, 1, 113.

[30] Potente H., Fischer P.: Kunststoffe 1977, 67, 242.

[31] Schenkel G.: Kunststoffe 1978, 68, 155.

[32] Chung C.I.: Polymer Engineering and Science 1984, 24 (9), 626 https://doi.org/10.1002/pen.760240904

[33] Rauwendaal C.: Polymer Engineering and Science 1987, 27 (14), 1059. https://doi.org/10.1002/pen.760271406

[34] Potente H.: International Polymer Processing 1991, 6 (4), 267. https://doi.org/10.3139/217.910267

[35] Covas J.A., Gaspar-Cunha A.: International Polymer Processing 2009, 24 (1), 67. https://doi.org/10.3139/217.2200

[36] Gaspar-Cunha A., Covas J.A.: International Journal of Natural Computing Research 2014, 4 (1), 17. https://doi.org/10.4018/ijncr.2014010102

[37] Denysiuk R., Recio G., Covas J.A., Gaspar-Cunha A.: Polymer Engineering and Science 2018, 58 (4), 493. https://doi.org/10.1002/pen.24732

[38] Gaspar-Cunha A., Covas J.A.: "A Scaling-up Methodology for Co-rotating Twin-Screw Extruders", Materiały konferencyjne (PPS-27), Marrakesz, Maroko, 10--14 maja 2011 r., str. 1-6.

[39] Berzin F., David C., Vergnes B.: International Polymer Processing 2020, 35 (5), 422. https://doi.org/10.1515/ipp-2020-350504

[40] Nastaj A., Wilczyński K.: Polymers 2021, 13 (10), 1547. https://doi.org/10.3390/polym13101547

[41] Wilczyński K.: „Rheology in Polymer Processing. Modeling and Simulation", Carl Hanser Verlag, Munich 2021.

[42] Wilczynski K., Nastaj A., Lewandowski A., Wilczyński K.J.: Polymer-Plastics Technology and Engineering 2012, 51 (6), 626. https://doi.org/10.1080/03602559.2012.659313

[43] Wilczyński K., Lewandowski A., Wilczyński K.J.: Polymer Engineering and Science 2012, 52 (6), 1258. https://doi.org/10.1002/pen.23076 
[44] Wilczyński K., Nastaj A., Wilczyński K.J.: International Polymer Processing 2013, 28 (1), 34. https://doi.org/10.3139/217.2640

[45] Wilczyński K.J., Nastaj A., Lewandowski A., Wilczyński K.: Polymer Engineering and Science 2014, 54 (10), 2362. https://doi.org/10.1002/pen.23797

[46] Wilczyński K.J., Lewandowski A., Nastaj A., Wilczyński K.: International Polymer Processing 2016, 31 (1), 82. https://doi.org/10.3139/217.3154

[47] Wilczyński K.J., Lewandowski A., Nastaj A., Wilczyński K.: Advances in Polymer Technology 2017, 36 (1), 23.

https://doi.org/10.1002/adv.21570
[48] Wilczyński K.J., Lewandowski A., Wilczyński K.: Polymer Engineering and Science 2016, 56 (12), 1349. https://doi.org/10.1002/pen.24368

[49] Wilczyński K.J., Nastaj A., Wilczyński K.: Advances in Polymer Technology 2018, 37 (6), 2142. https://doi.org/10.1002/adv.21873

[50] Wilczyński K., Nastaj A., Lewandowski A. et al.: International Polymer Processing 2015, 30 (1), 113. https://doi.org/10.3139/217.3007

[51] Wilczyński K., Buziak K., Wilczyński K.J. et al.: Polymers 2018, 10 (3), 295. https://doi.org/10.3390/polym10030295

[52] Wilczyński K., Nastaj A., Lewandowski A. et al.: Polymers 2019, 11 (12), 2106. https://doi.org/10.3390/polym11122106

Otrzymano 5 V $2021 r$.

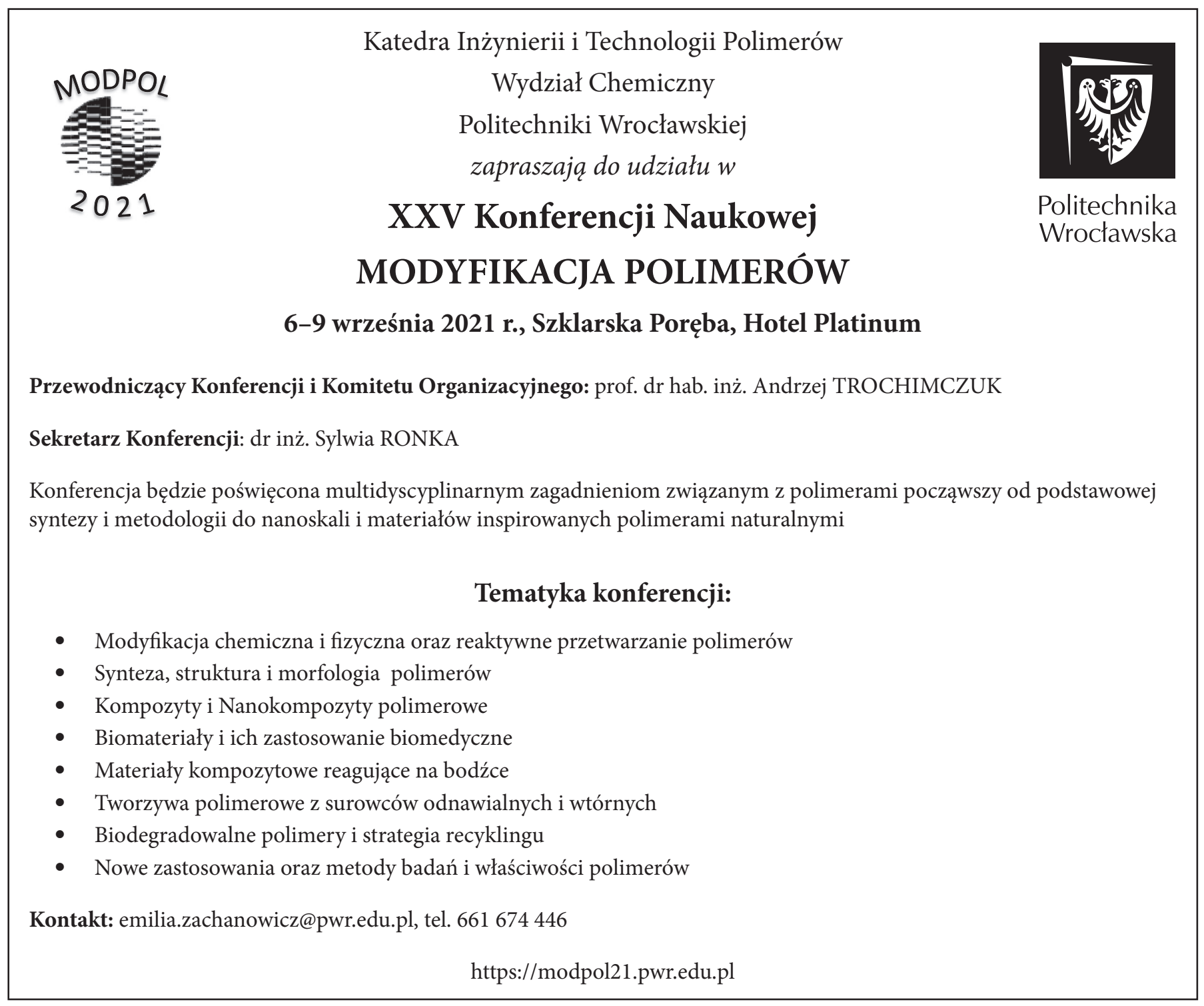

